\title{
PELATIHAN PENGELOLAAN WEBSITE TOKO ONLINE BAGI UMKM DI KAWASAN PASAR TRADISIONAL KLEWER SURAKARTA SEBAGAI STRATEGI MENGHADAPI MASYARAKAT EKONOMI ASEAN (MEA)
}

\author{
Mohamad Suharto ${ }^{1}$, Deny Tri Ardhianto ${ }^{2}$, Anugrah Irfan Ismail ${ }^{3}$, \\ Nadia Sigi Prameswari ${ }^{4}$ \\ ${ }^{123}$ Fakultas Seni Rupa dan Desain, Universitas Sebelas Maret Surakarta \\ ${ }^{4}$ Fakultas Keguruan dan IImu Pendidikan, Universitas Sebelas Maret Surakarta
}

\begin{abstract}
Abstrak: Tujuan kajian ini adalah memberikan pengetahuan tentang peran toko online (online shop) untuk tingkat pemula bagi UMKM yang belum memiliki toko online atau memiliki kendala dalam memasarkan produknya melalui media online di kawasan pasar tradisional Klewer Surakarta. Metode penelitian adalah studi literatur, observasi dan wawancara. Observasi dilakukan pada proses jual beli antara pemilik usaha dengan calon pembeli sehingga dapat diketahui sejauh mana kekurangan dan kelebihan pemilik usaha dalam melayani calon pembeli. Pendekatan yang digunakan adalah pendekatan kolaboratif, antara UMKM dan tim peneliti secara kolaboratif bersama-sama saling mewujudkan program pelatihan pengembangan dan pengelolaan website toko online sebagai strategi dalam menghadapi persaingan pasar. Pelatihan pengelolaan website toko online bagi UMKM sangat dibutuhkan dalam menunjang pemasaran produk di kawasan pasar tradisional Klewer Surakarta. Dengan cara tersebut pemilik usaha memiliki pengetahuan baru mengenai teknologi informasi khususnya dalam mengelola website toko online sebagai salah satu media pemasaran. Dengan memiliki website toko online, akan dapat menekan biaya promosi yang biasanya menggunakan media promosi cetak, seperti: brosur, katalog, iklan majalah dan lain-lain yang membutuhkan biaya yang tinggi. Selain itu toko online memiliki jangkauan yang luas untuk menjangkau calon pembeli. Adanya website toko online akan membantu pengembangan pemasaran usaha dan dapat meningkatkan penjualan.
\end{abstract}

Kata Kunci : toko online, pasar tradisional, Masyarakat Ekonomi Asean (MEA).

Penulis adalah beberapa staf pengajar di Universitas Sebelas Maret Surakarta, email: nadiasigi87@gmail.com. 


\begin{abstract}
The purpose of study aim to provide knowledge about the role of online shop for beginners who do not have an online store or have difficulties in marketing their products through online media in Klewer Surakarta traditional market area. The method used in this research is literature study, observation and interview. Observations made on the process of buying and selling between business owners with prospective buyers so it can be known how far the lack and excess of business owners in serving prospective buyers. The approach used in this study with a collaborative approach, between SMEs and research teams collaboratively work together mutually realize the training program development and management of online store website as a strategy in dealing with market competition. Online store website management training for MSME is needed in supporting the marketing of products in Klewer Surakarta traditional market area. In this way business owners have new knowledge about information technology, especially in managing website of online store as one of marketing media. By having an online store website, will be able to reduce the cost of promotions that usually use print media campaigns, such as: brochures, catalogs, magazine ads and others that require high fees. In addition, online stores have a wide reach to reach potential buyers. The existence of an online store website will help the development of business marketing and can increase sales.
\end{abstract}

Keywords: online shop, traditional market, Asean Economic Community (MEA).

\title{
PENDAHULUAN
}

Di kota Surakarta terdapat salah satu pusat perdagangan berbagai macam pakaian khususnya pakaian batik. Pasar Klewer merupakan salah satu pasar terbesar di Jawa Tengah. Nama Pasar Klewer berasal dari bahasa Jawa yaitu "Kleweran" yang yang berarti penjual pakaian meletakkan barang dagangannya dan susunan kainnya ke bahu penjual secara tidak beraturan. Dari istilah tersebut berkembang menjadi pasar dan menjadi nama Pasar Klewer.

Pasar Klewer memiliki luas lahan $12.950 \mathrm{~m} 2$ dan berada di sebelah barat Keraton Kasunanan Surakarta Hadiningrat. Kegiatan utama Pasar Klewer berupa 
perdagangan dengan komoditi utama adalah tekstil dan komoditi sekunder sebagai penunjang kegiatan utama perdagangan seperti aksesoris pakaian, dan barang dagangan lainnya. Pasar Klewer merupakan salah satu pasar terbesar di Kota Surakarta yang menjadikan pasar ini sebagai pusatnya produk produk dengan harga grosir. Dengan produk utamanya berupa sandang, menjadikan Pasar Klewer sebagai tempat utama dari produksi kain batik di wilayah kota Surakarta seperti daerah Kauman, Laweyan dan Pasar Kliwon. Bahkan sampai sekarang Pasar Klewer berkembang dan menampung berbagai macam komoditas dari banyak daerah di Indonesia.

Menurut Wiharto (2006), masuknya kekuatan ekonomi besar tidak dapat terbendung dalam ekspansi ekonomi dunia sehingga membuka peluang kearah liberalisasi ekonomi dunia semakin mapan karena proyeksi pemberlakuan pasar bebas melalui MEA. Pasar tradisional masih sangat dibutuhkan oleh banyak masyarakat, karena pasar bukan hanya untuk transaksi jual beli, namun juga sebagai tempat hidup dan interaksi sosial. Pasar bukan hanya pusat kegiatan ekonomi saja, akan tetapi para pelaku usaha dapat mencapai tujuan lain (Adiwisono, 1989). Dengan situasi sekarang ini, daya tarik pasar menjadi turun, hal itu diakibatkan oleh kondisi pasar yang buruk dan sarana prasarana di dalam pasar tradisional yang tidak terawat. Penataan pasar yang tidak tertata, terbatasnya ruang gerak di dalam pasar, ventilasi udara di dalam pasar yang membuat ruangan jadi sumpek. Sangat berbeda dengan kondisi yang di alami oleh pasar modern (Sunoko, 2006).

Dengan keadaan seperti itu maka diperlukan satu terobosan baru mengingat semakin ketatnya persaingan usaha. Pemanfaatan teknologi sangat mempengaruhi perkembangan usaha. Apabila UMKM pasar tradisional tidak segera melakukan pembenahan, maka dengan persaingan ekonomi yang ketat akan mengakibatkan UMKM kalah dalam bersaing. Hal itu menjadikan perlunya 
dilakukan pembenahan terhadap UMKM dan menjaga hubungan baik antara UMKM dengan konsumnen dan pelanggan untuk jangka panjang (Ghobakhloo, Sabouri, Hong \& Zulkifli, 2011). Pembenahan yang perlu dilakukan salah satunya adalah dengan memanfaatkan media promosi berupa pembuatan media toko online. Manfaat dari toko online antara lain dapat meningkatkan produktivitas dan pemasaran UMKM melalui jaringan internet yang dapat menghubungkan secara langsung dengan pelanggan atau konsumen.

\section{Dinda Batik (Mitra UMKM 1)}

Dinda Batik didirikan oleh Sri Winarsih sekitar sepuluh tahun silam. Dinda Batik berlokasi di kawasan Pasar Klewer dengan alamat Cinderamata, Timur Alunalun Utara, Surakarta. Setiap harinya Sri Winarsih berjualan baju batik dan kaos merchandise khas Solo di lapak usahanya yang berukuran $2,5 \mathrm{~m} \times 2,5 \mathrm{~m}$. Dengan keterbatasan lahan yang dimilikinya Sri Winarsih berusaha memanfaatkan semaksimal mungkin dalam mendisplay produk produk baju batik dan kaos merchandise khas Solo. Produk yang di jual seperti baju batik dan kaos merchandise khas Solo, baik untuk anak-anak hingga dewasa.
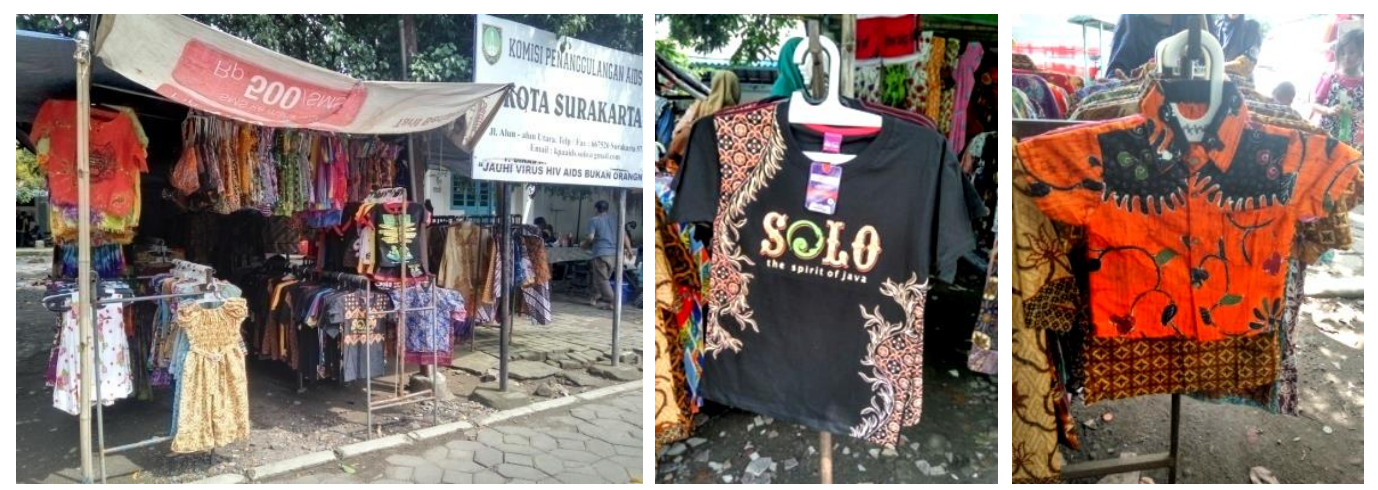

Gambar 1. Stand Dinda Batik dan Produk yang Dijual.

(Sumber: dokumentasi penulis) 
Beberapa bulan terakhir ini penjualan Dinda Batik mengalami penurunan, hal itu dikarenakan 2330ok233g hujan, selain itu pengunjung di daerah cinderamata semakin menurun di hari biasa. Hari yang biasa ramai pengunjung adalah hari Minggu. Kebanyakan pembeli berasal dari luar kota, sedangkan untuk pembeli dari penduduk Surakarta tergolong kecil. Dalam 2 bulan terakhir, untuk omset per hari yang di dapat dari menjual baju sekitar Rp 50.000 sampai Rp 150.000 pada hari biasa. Dan untuk omset perhari pada hari Minggu sekitar Rp 200.000 sampai Rp 500.000. Permasalahan utama yang dihadapi Sri Winarsih selama ini dalam mengembangkan usahanya adalah keterbatasan lahan dalam mendisplay produk baju, selain itu juga bangunan yang di bangun tidak permanen, (bongkar-pasang), sehingga seringkali calon pembeli hanya melihat-lihat barang dan tidak membeli baju karena keterbatasan pilihan baju yang ada di display produk. Sri Winarsih berharap ada pengembangan pemasaran yang berbeda dari selama ini yang dijalankannya agar penjualannya dapat meningkat walaupun di hari biasa.

\section{Bunga Fashion (Mitra UMKM 2)}

Bunga Fasion didirikan oleh Rini Haryati sekitar sepuluh tahun silam. Bunga Fasion berlokasi di kawasan Pasar Klewer dengan alamat Cinderamata, Timur Alun-alun Utara, Surakarta. Setiap harinya Rini Haryati berjualan baju batik dan kaos merchandise khas Solo di lapak usahanya yang berukuran $3 \mathrm{~m} \times 3 \mathrm{~m}$. Setiap hari Rini Haryati berjualan tanpa dibantu orang lain. Dengan lahan yang terbatas, Rini Haryati mendisplay berbagai produk baju yang dimilikinya. Produk yang di jual seperti baju batik dan kaos merchandise khas Solo untuk ukuran anak-anak sampai ukuran dewasa. Beberapa bulan terakhir, penjualan yang diperoleh Bunga Fashion mengalami penurunan. Bangunan yang sempit dan tidak permanen (bongkarpasang) menjadikan omset penjualan menurun 233 ook $233 \mathrm{~g} 233$, terlebih di musim hujan. Bahkan jika hujan berlangsung dalam waktu lama, terpasaka 233ook tutup lebih awal. 

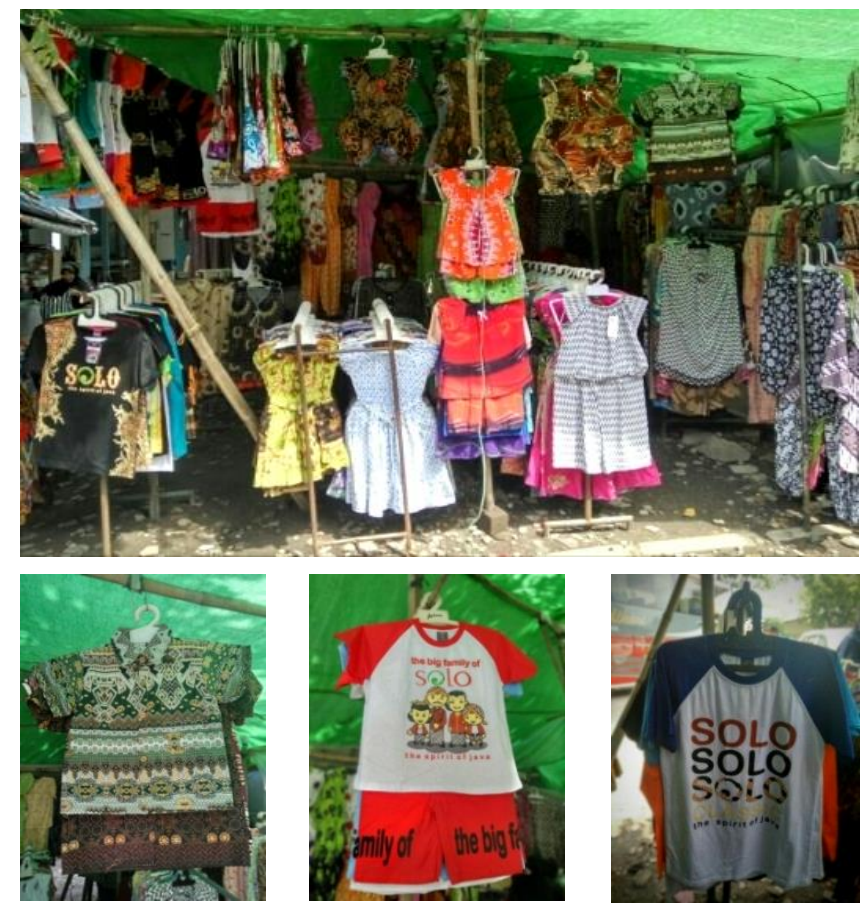

\section{Gambar 2. Stand Bunga Fashion dan Produk yang Dijual.}

(Sumber: dokumentasi penulis)

Dalam 2 bulan terakhir, omset penjualan per hari yang didapat sekitar Rp 50.000 sampai Rp 200.000 pada hari biasa. Dan untuk omset perhari pada hari minggu sekitar Rp 200.000 sampai Rp 1.000.000. Hal itu tergantung pada banyak tidaknya pengunjung dari luar kota. Permasalahan yang dihadapi selama ini adalah penjualan yang dilakukan hanya mengandalkan pembeli yang 234 ook $234 \mathrm{~g}$ di kiosnya saja. Tidak ada media pemasaran lain yang dilakukan, sehingga perkembangan usahanya sangat lambat. Rini Haryati ingin melakukan hal baru dalam pengembangan usaha, tetapi terkendala waktu. Karena usaha yang dijalankan hanya sendiri tidak dibantu orang lain, Rini Haryati berharap ada pengembangan pemasaran yang berbeda dari selama ini yang dijalankannya agar penjualannya dapat meningkat.

Situasi tersebut mendasari bahwa pelatihan dan pendampingan bagi usaha Bunga Fashion dan Dinda Batik sangat penting. Pendampingan memfokuskan pada 
pengembangan strategi pemasaran khususnya melalui media website 235 ook online sehingga dapat menjangkau target pasar yang lebih luas bukan hanya di daerah kawasan Pasar Klewer tetapi juga di luar daerah lain.

Penulisan artikel ini akan memberikan informasi mengenai pentingnya pelatihan pengelolaan website $23500 k$ online untuk tingkat pemula di kawasan pasar tradisional Klewer Surakarta dengan tujuan dapat bersaing dengan para pelaku usaha sejenis yang sudah menggunakan 235 ook online. Selain itu juga merupakan strategi dalam menghadapi perdagangan bebas melalui masyarakat ekonomi Asean (MEA).

Berpijak pada kondisi tersebut, maka dapat ditarik rumusan masalah sebagai berikut: 1) Bagaimana memberikan pengetahuan kepada pemilik usaha mengenai teknologi informasi, dan 2) Bagaimana inovasi media pemasaran bagi pemilik usaha dalam menghadapi persaingan usaha sejenis yang semakin meningkat ditengah keterbatasan modal dan tenaga kerja.

\section{KAJIAN TEORI}

\section{Web Desain}

Gunarsih, Utami dan Yusup (2016) mengemukakan bahwa desain web adalah istilah yang sering digunakan dalam suatu situs web yang ditampilkan pada penggunanya lewat sebuag browser web atau perangkat lunak berbasis web.

\section{a. Fungsi Web Desain}

Web desain memiliki beberapa funsi situs web dengan tujuan desain yang dibuat sudah sesuai, berikut adalah fungsi situs web:

1) Fungsi Komunikasi

Website memiliki fungsi sebagai media komunikasi pada umumnya, web dinamis dibuat karena menggunakan pemrograman web (server side) 
yang dilengkapi dengan fasilitas beserta fungsi-fungsi komunikasi seperti: web mail, formanthec, chatting, forum, dll.

2) Fungsi Informasi

Berikut adalah fungsi infomasi website:

a) Tujuan dari website adalah menyampaikan isi yang didalamnya terdapat kualitas konten sebuah website.

b) Sebaiknya berisi teks dan grafis.

c) Berfungsi sebagai penyampai informasi, news, file, company, library, dan prefences.

3) Fungsi Entertainment

Situs web juga memiliki fungsi media hiburan seperti penggunaan animasi gambar atau elemen bergerak lainnya yang diharapkan akan meningkatkan mutu desain web. Namun dengan adanya animasi gambar beresiko mengurangi kecepatan downloadnya. Contoh fungsi entertainment : game online, film online, music online.

4) Fungsi Transaksi

Sekarang ini website dapat difungsikan sebagai transaksi jual beli baik itu berupa barang maupun jasa. Melalui situ website, dapat menghubungkan antara perusahaan (produsen) dan juga konsumen. Pembayaran dapat dilakukan melalui transaksi elektronik. Pembayarannya bisa melalui kartu kredit, transfer atau membayar langsung.

\section{Toko Online / Online shop}

Online shop atau yang dikenal juga bisnis online saat ini sangat tidak asing di telinga kita. Sekarang ini masyarakat Indonesia yang sudah menggunakan online shop baik itu sebagai pemilik online shop maupun sebagai konsumen. Online shop adalah suatu proses transaksi jual beli barang dan jasa dengan menggunakan 
jaringan internet sebagai medianya, dimana para pembeli dan penjual tidak saling bertemu secara fisik dalam melakukan transaksi. Produk yang diperjualbelikan ditawarkan melalui sebuah website yang di dalamnya terdapat display dengan gambar produk. Konsumen dapat memilih produk yang diinginkan dan jika sesuai maka dapat melakukan pembayaran kepada penjual melalui rekening bank. Setelah konsumen sudah melakukan pembayaran, maka penjual wajib mengirim barang pesanan pembeli ke alamat tujuan. Ketersediaan informasi dan desain kemasan yang menarik dapat mendorong seseorang untuk membeli barang secara online (Widyanto, 2015).

Salah satu faktor penting dalam menjalankan toko online adalah pemilihan produk yang akan dijual. Beberapa kategori produk yang dapat dijual dan memiliki penjualan retail terbanyak, yaitu barang kebutuhan sehari-hari, pakaian, barang elektronik, kebutuhan kantor, aksesories, buku/CD/VCD, peralatan rumah tangga, produk handmade, makanan, produk kesehatan, perhiasan, dan alat-alat olahraga.

\section{Pasar Tradisional}

Pasar tradisional adalah pasar yang melaksanakan kegiatan ekonominya secara tradisional atau konvensional, sebagai tempat pembeli dan penjual bertemu secara langsung, sebagai tempat terjadinya tawar menawar harga dan tercapai kesepakatan harga. Pasar tradisional biasanya menyediakan bermacam macam bahan kebutuhan pokok rumah tangga baik kebutuhan premier, sekunder maupun tersier. Sasanto dan Yusuf (2010) mendefinisikan pasar tradisional sebagai arena pertukaran kebutuhan hidup sehari-hari dan sudah dikenal sejak dahulu kala, sebelum masyarakat mengenal uang. Pada zaman itu masyarakat masih lebih banyak memenuhi sendiri kebutuhan konsumsinya, dan penyelenggaraan hari pasar tidak dilakukan setiap harinya, namun pada hari tertentu saja, yang lebih dikenal dengan hari pasaran. Ketika masyarakat sudah 
mengenal uang sebagai alat yang sah untuk jual beli, maka pasar dikelola oleh pemerintah melalui Dinas Pasar.

Karakteristik pasar tradisional diantaranya secara fisik terlihat kurang baik meskipun sebagian sudah ada yang terlihat baik. Secara kelembagaan Pasar Tradisional adalah milik masyarakat dan PEMDA, serta sedikit dari sektor swasta. Konsumen Pasar Tradisional umumnya masyarakat menengah kebawah. Jaringan Pasar Tradisional meliputi Pasar region, pasar kota, dan pasar kawasan (Utomo, 2011).

\section{Strategi Pemasaran}

Pemasaran didefinisikan sebagai suatu fungsi organisasi dan suatu perencanaan untuk menciptakan dan memberikan nilai kepada konsumen untuk membangun hubungan yang menguntungkan bagi pemangku kepentingn serta untuk dapat menciptkan pertukaran yang memuaskan tujuan individu maupun organisasi (Kotler dan Keller, 2009).

Menurut Chandra dalam Wibowo (2015) strategi pemasaran dapat diartikan sebagai rencana yang menjelaskan mengenai ekspektasi perusahaan tentang dampak yang timbul dari aktivitas pemasaran terhadap permintaan produk di pasar tertentu. Secara singkat, strategi pemasaran didefinisikan sebagai suatu proses pengambilan keputusan mengenai pemasaran, pembiayaan, alokasi pemasaran dengan keadaan lingkungan yang diharapkan dan kondisi persaingan.

\section{Metode Penelitian}

\section{Tempat dan Waktu Penelitian}

Penelitian ini dilakukan dengan mengambil subjek pemilik usaha yang ada di kawasan Pasar Klewer kota Surakarta. Waktu penelitian dilakukan pada periode Januari - Maret tahun 2017. 


\section{Metode Pendekatan Penelitian}

Metode dalam penelitian ini menerapkan observasi dan wawancara. Observasi dilakukan pada proses jual beli antara pemilik usaha dengan calon pembeli sehingga dapat diketahui sejauh mana kekurangaan dan kelebihan pemilik usaha dalam melayani calon pembeli. Hal ini juga diperkuat dengan melakukan wawancara dengan calon pembeli baik yang membeli produk maupun yang tidak membeli produk untuk mengetahui apa diinginkan pembeli.

Adapun pendekatan dalam penelitian ini menggunakan pendekatan kolaboraif, antara peserta dan tim peneliti secara kolaboratif bersama-sama saling mewujudkan program pengembangan website toko online dan pemasaran agar dapat berjalan dengan lancar, tanpa ada salah satu yang dianggap lebih penting atau tinggi dibandingkan yang lainnya. Dengan menerapkan metode ini maka hasil yang dicapai diharapkan dapat maksimal, karena kedua pihak sama-sama memberikan kontribusi yang sama-sama positif.

\section{Hasil dan Diskusi}

1. Pelatihan Pembuatan Toko Online bagi UMKM di Kawasan Pasar Tradisional Klewer Surakarta.

Berdasarkan hasil observasi dan wawancara yang dilakukan terhadap kedua UMKM di kawasan pasar tradisonal Klewar Surakarta adalah keterbatasan modal yang dimiliki UMKM sehingga keuntungan yang didapatkan hanya dapat digunakan untuk membeli barang dagangan semata. Kondisi tersebut menjadikan tidak adanya peningkatan yang lebih baik terhadap kondisi stand penjualan yang selama ini digunakan untuk berdagang. Hal itu tentunya juga memberikan dampak terhadap ketidakmampuan UMKM dalam memperluas media promosi dan pemasaran. 
Pelatihan keterampilan yang diperlukan bagi UMKM dalam menghadapi Masyarakat Ekonomi Asean (MEA) adalah pelatihan di bidang teknologi informasi. Pelatihan ini meliputi:

a. Keterampilan dalam mengoprasikan sistem website e-commerce yang merupakan toko online pribadi bagi UKM. Target yang harus dicapai dalam pelatihan ini adalah UMKM dapat menginput data produk-produk yang diperdagangkan beserta deskripsi mengenai produk dan harga.

b. Tidak cukup sampai disitu, UMKM diberikan keterampilan fotografi produk tingkat dasar agar mampu menghasilkan foto yang berfungsi sebagai ilustrasi peda website.

c. Pelatihan dalam strategi komunikasi pada sosial media untuk memperkenalkan website toko online masing-masing UMKM.

Kegiatan pengabdian yang telah dilaksanakan dengan bentuk kegiatan sebagai berikut:

a. Pembuatan website toko online berdasarkan hasil observasi dan wawancara kepada pelanggan "Bunga Fasion dan Dinda batik" dan sesuai dengan keinginan pemilik usaha "Bunga Fasion dan Dinda batik".

b. Pelatihan dalam mengoperasionalkan website toko online, meliputi: tahapan posting atau memperbaharui informasi hingga pengelolaan website. Hasil akhir yang didapat adalah UMKM dapat berperan sebagai admin dari website toko online pribadinya.

c. Pelatihan strategi marketing online melalui sosial media.

2. Inovasi Media Pemasaran bagi UMKM dalam Menghadapi Persaingan Pasar melalui Website Toko Online Non-Transaksi. 
Pengembangan website toko online merupakan sebuah inovasi terhadap media pemasaran yang luas dan tak terbatas. Adapun konsep dari website toko online yang diterapkan pada UMKM adalah website nontransaksi yang hanya berfungsi sebagai informasi dan komunikasi tidak langsung. Hal itu disesuaikan dengan kebutuhan UMKM dan keterbatasan tenaga yang dimilikinya sehingga sangat tidak memungkinkan apabila melayani transaksi langsung pada sistem. Oleh karena itu konsumen dapat langsung menghubungi pihak UMKM atau langsung mendatangi stand untuk melakukan pembelian.

\section{Model Web Toko Online Non-Transaksional}

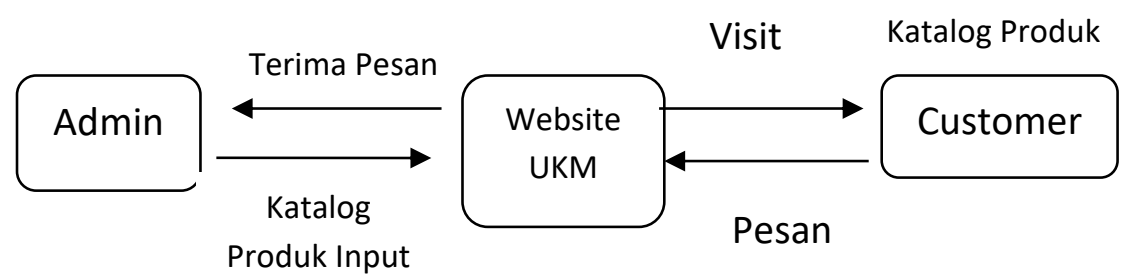

Model website toko online non-transaksional

(Sumber: dokumentasi penulis)

\section{Draf Desain Website Toko Online}

\section{a. Draf Desain Website Toko Online untuk Homepage}

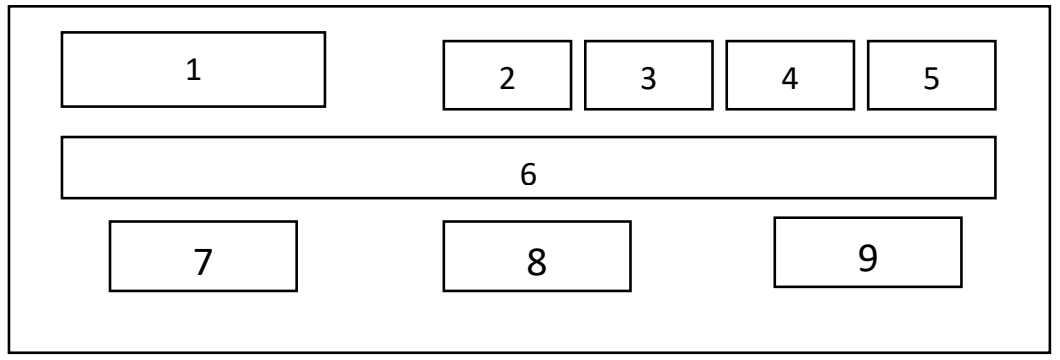

\section{Keterangan :}
1. Logo UKM
4. Gallery
7. Produk 1
2. Home
5. Contact
8. Produk 2
3. Tentang Kami
6. Web Banner
9. Produk 3 
Draf desain website toko online untuk homepage

(Sumber: dokumentasi penulis)

\section{b. Draft Desain Web Toko Online untuk Detail Produk}

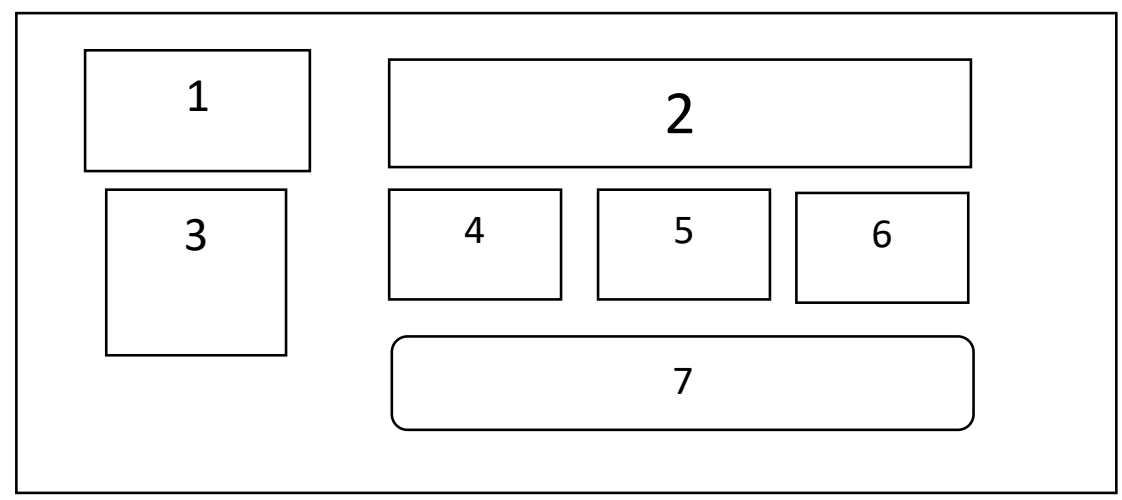

\section{Keterangan :}

1. Gambar Produk

5. Tampilan Produk 2

2. Nama \& Harga Produk

6. Tampilan Produk 3

3. Deskripsi Produk

7. Produk Terkait

4. Tampilan Produk 1

Draf desain website toko online untuk detail produk

(Sumber: dokumentasi penulis)

\section{Desain Web}

\section{a. Desain Web Dinda Batik (www.dindabatik.com)}

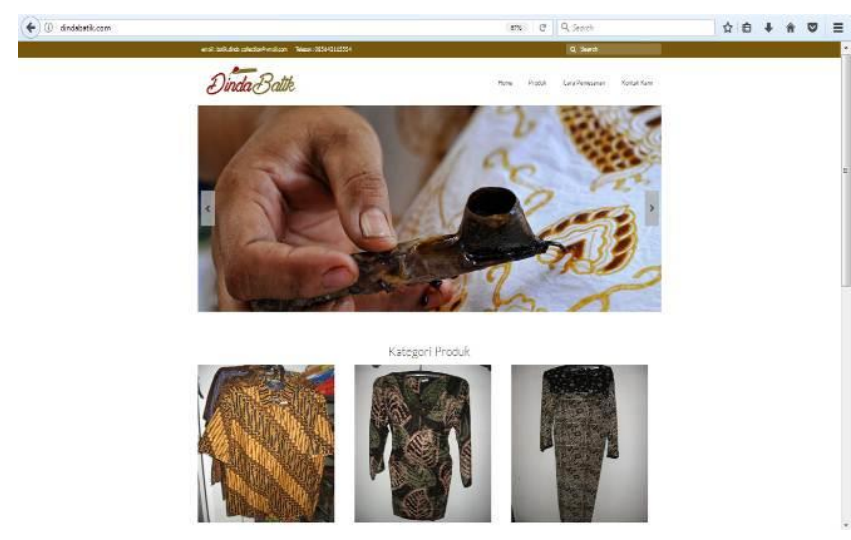

Homescreen Dinda Batik

(Sumber: dokumentasi penulis) 


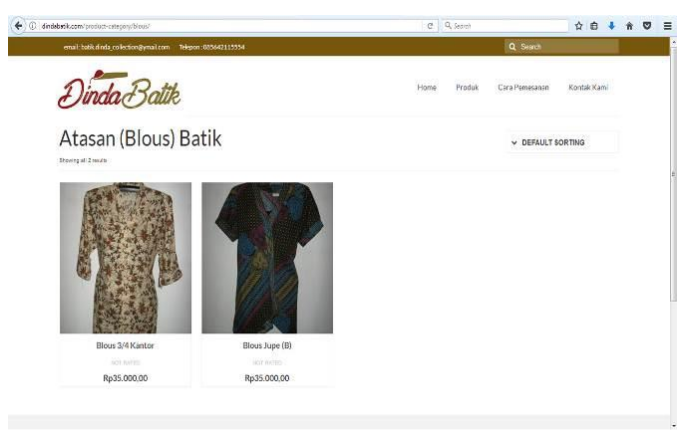

Galeri Produk

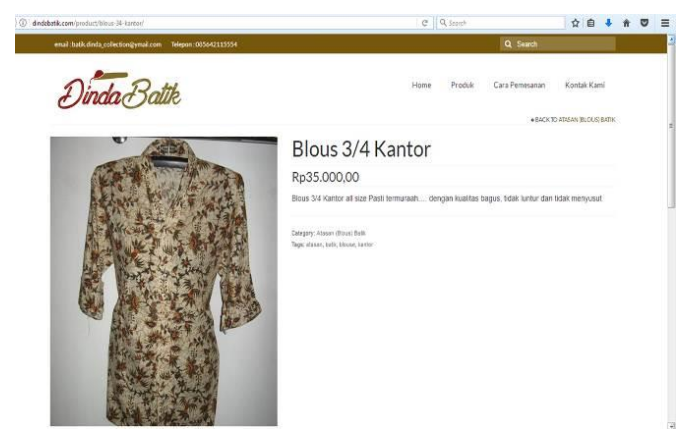

Detail Produk

(Sumber: dokumentasi penulis)

b. Web Bunga Fashion (www.bungafashion.com)

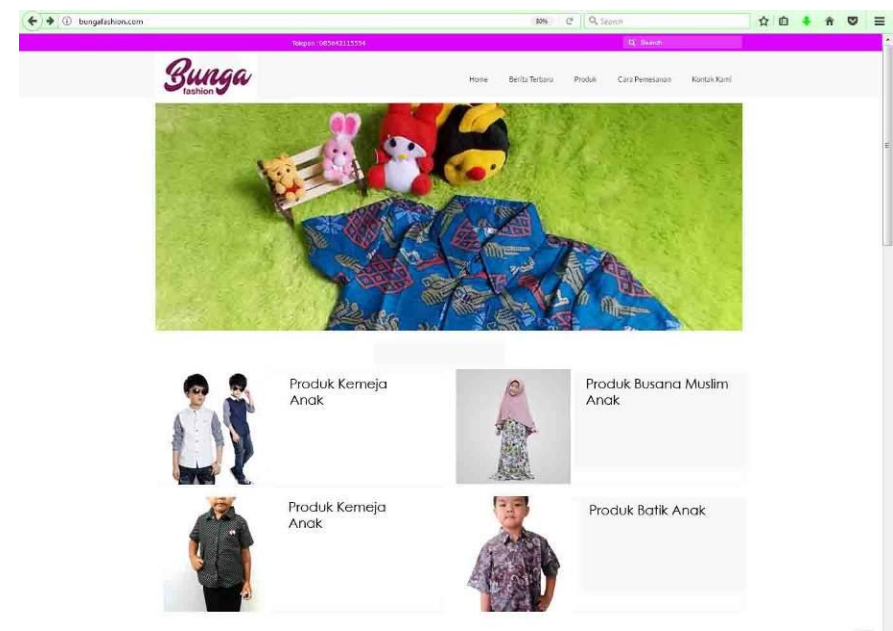

Homescreen Bunga Fashion

(Sumber: dokumentasi penulis)

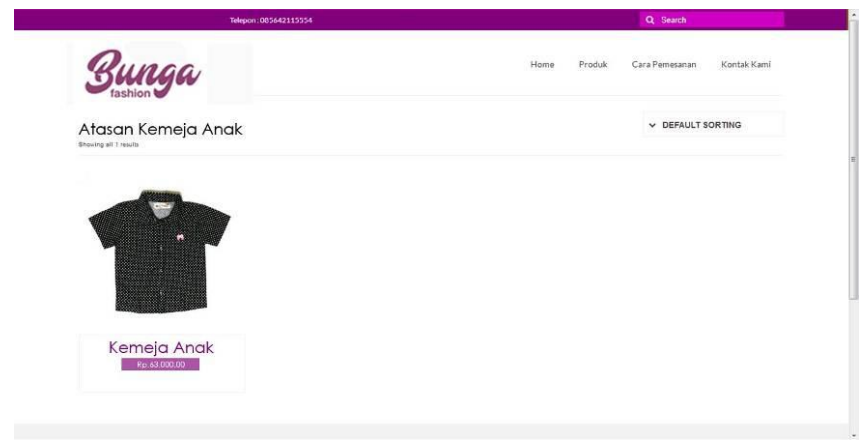

Galeri Produk Bunga Fashion

(Sumber: dokumentasi penulis) 


\section{Desain Logo UKM Dinda Batik \& Bunga Fashion}
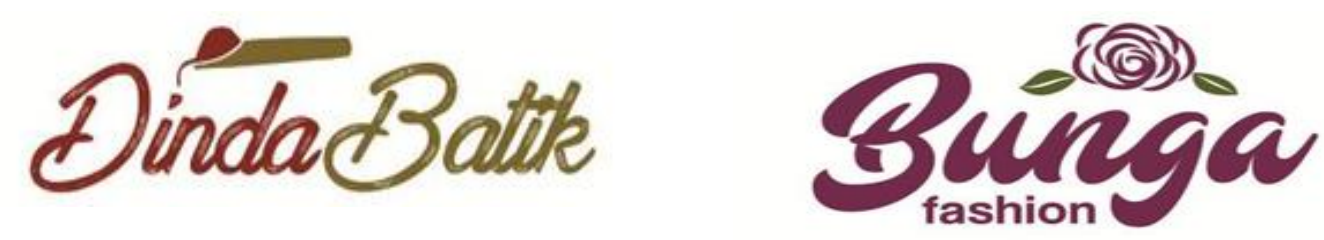

Desain logo UKM dindabatik.com dan bungafashion.com

(Sumber: dokumentasi penulis)

\section{Kesimpulan}

Pelatihan pengelolaan website toko online bagi UMKM sangat dibutuhkan dalam menunjang pemasaran produk di kawasan pasar tradisional Klewer Surakarta. Dengan cara tersebut pemilik usaha memiliki pengetahuan baru mengenai teknologi informasi khususnya dalam mengelola website toko online sebagai salah satu media pemasaran. Dengan memiliki website toko online, akan dapat menekan biaya promosi yang biasanya menggunakan media promosi cetak, seperti: brosur, katalog, iklan majalah dan lain-lain yang membutuhkan biaya yang tinggi. Selain itu toko online memiliki jangkauan yang luas untuk menjangkau calon pembeli. Adanya website toko online akan membantu pengembangan pemasaran usaha dan dapat meningkatkan penjualan.

\section{Pernyataan Penghargaan}

Terimakasih kepada LPPM UNS atas dukungan finansial yang telah diberikan sehingga penelitian ini dapat berjalan dengan lancar.

\section{Daftar Pustaka}

Ghobakhloo, M., Sabouri, M.S., Hong, T.S., Zulkifli, N., 2011. Information Technology Adoption in Small and Medium-sized Enterprises; An appraisal of two literature. Interdisciplinary Journal of Research in Business, 1 (7), pp. 53-80.

Gunarsih, Tri, Utami, Ristianawati Dwi \& Yusup, 2011, Pengaruh Desain Web dan Kualitas Informasi Terhadap Minat Pembelian Pada Toko Online, diunduh 
pada 30 Mei 2017, dari http://uty.ac.id/2011/08/pengaruh-desain-webdan-kualitas-informasi-terhadap-minat-pembelian-pada-toko-online/

Kahar Sunoko, 2006, Pasar Tradisional, Seminar Perencanaan Pasar Tradisional Menghadapi Tekanan Hypermarket di Perkotaan, FT UNS.

Kotler, P., \& Keller, K.L. (2009). Manajemen Pemasaran, edisi ketiga belas. Jakarta: Erlangga.

Riga Adiwisono S, 1989, Interaksi Jual Beli dan Komunikasi di Tempat Belanja, Prisma, Jakarta.

Sasanto, Reza \& Yusuf, Muhammad, 2010, Identifikasi Karakteristik Pasar Tradisional di Wilayah Jakarta Selatan (Studi Kasus : Pasar Cipulir, Pasar Kebayoran Lama, Pasar Bata Putih dan Pasar Santa, Jurnal Planesa, Volume 1, Nomer 1

Utomo, Tri Joko, 2011, Persaingan Bisnis Ritel: Tradisional Vs Modern (The Competition of Retail Business: Traditional vs Modern), Fokus Ekonomi, Vol. 6 No. 1 Juni, pp. $122-133$

Wibowo, Dimas Hendika, Arifin, Zainul \& Sunarti, 2015, Analisis Strategi Pemasaran Untuk Meningkatkan Daya Saing UMKM (Studi Pada Batik Diajeng Solo), Jurnal Administrasi Bisnis (JAB), Vol. 29 No.1

Widyanto, Ibnu \& Prasilowati, Sri Lestari, 2015, Perilaku Pembelian Melalui Internet, JMK, Vol. 17, No. 2, September 2015, pp. 109-112

Wiharto, 2006, Ekspansi Hypermarket dan Pengaruhnya Terhadap Pasar Tradisional, Seminar Perencanaan pasar Tradisional Menghadapi Tekanan Hypermarket di Perkotaan, FT UNS. 